\title{
1 \\ China: new engine of world growth
}

\section{Ross Garnaut}

China is now the centre of attention for international business. For the main global producers of travel and financial services, resources, electronic products, aeroplanes and machines, the annual reports this year contain statements about the importance of the China market to growth.

There is good reason for the focus on China. Since the eve of financial crisis in Korea and much of Southeast Asia in 1996, China has contributed one quarter of global growth in output and international trade. In the sluggish world economy since the Clinton-era boom in the United States ended in late 2000, China has contributed the whole of the global expansion in international trade. Over these years it has supplanted the United States as the world's largest recipient of direct foreign investment, with annual levels exceeding US $\$ 50$ billion.

These are immediate causes of the current international excitement about China. More important than these indicia of recent relative success, however, is an older reality. Over the quarter century since Deng Xiaoping won decisive control of the Central Committee of the Chinese Communist Party and moved policy decisively towards reform and opening to the outside world in 1978, economic output and international trade have expanded much more rapidly in China than in any other country, even through periods of exceptional prosperity in Asia, North America and Australasia.

These last half dozen years have been but one stage in what is inevitably a long and difficult Chinese journey towards the emergence of a productive modern economy. The last half dozen years have actually seen the lowest average growth for any 
period of comparable duration in the reform era, most importantly because the external environment has been exceptionally difficult.

The world is noticing Chinese economic success now not because economic reform and growth are different and more impressive in China (although the increase in economic mass that comes with sustained growth itself increases China's impact on the rest of the world, even if growth rates are a bit below earlier heights). The world is noticing now because the rest of the world is different. The rest of the world is growing more slowly, a weakened international trading system is supporting less growth in trade, and the United States is going through a period in which it is inclined to see China as a strategic partner rather than a rival. And the modernisation of China is a project of such immense dimension that those who turn their minds to it now and then have difficulty keeping it in perspective, with a consequence that expectations overshoot in both positive and negative directions.

The contemporary international excitement about China's economic performance should be a cause for caution rather than exuberance. The Chinese reality of reform and economic growth since 1978 has been much more stable than foreigners' perceptions of them.

The Chinese economy is likely to continue to perform relatively strongly on the pattern of the past quarter century. But as at each stage of the reform journey so far, success may be broken at any time by inadequate responses to immense challenges. Policy and institutional innovation of historic dimension on a world scale will continue to be necessary, to overcome barriers to growth as their importance becomes apparent through the process of reform. China's reform, international integration and growth will continue to make extreme demands on the quality of Chinese leadership and the energy and capacity for transformation within the Chinese people. It could not ever have been otherwise in an economic, political and social transformation on a scale that is unprecedented in human history.

It is not in the nature of Western businesspeople to reflect on what has gone before. But it takes little reflection to appreciate the volatility of Western expectations of China. It is only a year since books by Joe Studwell and Gordon Chang became bestsellers and part of every American business conversation about China predicted the imminent collapse of the Chinese economy and the Chinese Communist Party.

Australians over the past quarter century-officials, businesspeople and citizenshave been steadier than Americans in their perceptions of China. For the most part, they have been closer to the reality-less apocalyptic; less alarmist in the difficult 
times and less extreme in their enthusiasm in the better times. Less downbeat in the periodic inflationary crises of the first fifteen years of reform, in the dark days after the split in the Chinese leadership over management of the Tian An Men crisis and through the external challenges of the Asian financial crisis. A bit less excited in the periods of exceptional growth in domestic demand, Chinese ferment over political change, and more obvious identity between Chinese and Western strategic interests.

It is possible that the current Australian mood on China is absorbing more of the amplitude of the American, through the contemporary tendency for Australian business to look at its international opportunities through lenses ground in New York, California and Washington DC. This new assessment, in China: new engine of world growth, will help to place the Chinese reality into perspective.

The reality is much as it has been for the last 25 years of reform. Nothing is more important to the health of the global economy and especially of Australia's Asia Pacific neighbourhood than the success of China's efforts to build a productive market economy, deeply integrated into the international economy through mechanisms that promote trade on the basis of global comparative advantage. The good progress so far augurs well for the future of reform and growth in China. The challenges that remain are less daunting than some that have already been overcome. But the challenges of today and tomorrow are nevertheless immense.

\section{THE KEYNESIAN EXPANSION}

These last six years, since the collapse of the Thai baht heralded financial dislocation in much of East Asia and recession in more, have been more challenging for Chinese economic growth than any similarly extended period in the reform era. Growth has been sustained at rates comfortably above the 7.2 per cent that doubles output each decade and which has been an unheralded official target since Deng Xiaoping in 1980 promised that Chinese output would quadruple by the end of the century (Table 1.1). But this success was built on a risky strategy of Keynesian fiscal expansion with a fixed exchange rate that has costs for systemic efficiency and long-term growth. It was built on risks that no-one could define at all clearly when there was great uncertainty about the depth and duration of the Asian financial crisis and after that of the United States' recession. Now that we know how things turned out, we know that the risks were worth taking, although we also know that the costs that must be paid for in the period ahead were real and large. 
Table 1.1 Output growth and inflation performance in China, 1979-2003

\begin{tabular}{|c|c|c|c|}
\hline & $\begin{array}{c}\text { Gross Domestic } \\
\text { Product }\end{array}$ & $\begin{array}{l}\text { Retail Price } \\
\text { Index }\end{array}$ & $\begin{array}{c}\text { Consumer Price } \\
\text { Index }\end{array}$ \\
\hline 1979 & 7.6 & 2.0 &.. \\
\hline 1980 & 7.8 & 6.0 & .. \\
\hline 1981 & 5.2 & 2.4 & .. \\
\hline 1982 & 9.1 & 1.9 & .. \\
\hline 1983 & 10.9 & 1.5 & .. \\
\hline 1984 & 15.2 & 2.8 & .. \\
\hline 1985 & 13.5 & 8.8 & 9.3 \\
\hline 1986 & 8.8 & 6.0 & 6.5 \\
\hline 1987 & 11.6 & 7.3 & 7.3 \\
\hline 1988 & 11.3 & 18.5 & 18.8 \\
\hline 1989 & 4.1 & 17.8 & 18.0 \\
\hline 1990 & 3.8 & 2.1 & 3.1 \\
\hline 1991 & 9.2 & 2.9 & 3.4 \\
\hline 1992 & 14.2 & 5.4 & 6.4 \\
\hline 1993 & 13.5 & 13.2 & 14.7 \\
\hline 1994 & 12.6 & 21.7 & 24.1 \\
\hline 1995 & 10.5 & 14.8 & 17.1 \\
\hline 1996 & 9.6 & 6.1 & 8.3 \\
\hline 1997 & 8.8 & 0.8 & 2.8 \\
\hline 1998 & 7.8 & -2.6 & -0.8 \\
\hline 1999 & 7.1 & -3.0 & -1.4 \\
\hline 2000 & 8.0 & -1.5 & 0.4 \\
\hline 2001 & 7.3 & -0.8 & 0.7 \\
\hline 2002 & 8.0 & -1.3 & -0.8 \\
\hline Jan-Jun 2003 & 8.2 & -0.4 & 0.6 \\
\hline Average $1979-2002$ & 9.40 & 5.53 & .. \\
\hline Average 1979-1996 & 9.92 & 7.84 &.. \\
\hline Average 1997-2002 & 7.83 & -1.39 & 0.16 \\
\hline Variance 1979-1996 & 11.239 & 42.412 & .. \\
\hline Variance 1997-2002 & 0.348 & 1.846 & 2.307 \\
\hline $\begin{array}{l}\text { t-statistic for difference in the } \\
\text { of } 1979-96 \text { and } 1997-2002\end{array}$ & 2.521 & 5.661 & \\
\hline
\end{tabular}

Source: State Statistical Bureau, various years. Zhongguo Tongji Nianjian [China Statistical Yearbook], Zhongguo Tongji Chubanshe, Beijing. Created by Wing Thye Woo, Chapter 3 , this volume 
The systemic costs of heavy reliance on public expenditure to maintain growth since 1996 have been substantial, and future growth must contend with the legacy of expanded direct and contingent public debt.

However, some other elements of the policy response to the past six years of difficult external economic conditions have been helpful to long-term growth. The years in which growth has been sustained by fiscal expansion have also been the years in which China prepared for and then achieved entry into the World Trade Organization. WTO entry supported the continuation of the radical trade liberalisation of the reform era when the political economy of change might have been expected to force some easing of the pace. These were also the years in which the legitimacy of the private sector's role in the economy was recognised by constitutional amendment, in which legislative and governmental reform was implemented to facilitate private sector growth, and in which rapid and extensive growth in the private sector came to contribute a majority of the country's economic output for the first time.

Thus two major elements of the policy response to external weakness pulled in opposite directions. The maintenance of growth in aggregate demand through increased direct public expenditure and lending by the state-owned banks to other state-owned enterprises was a step backwards into a larger role for unproductive entities. But the recognition at this time that the state sector could deliver neither the rapid increase in productivity nor the strong employment growth necessary to sustain political stability through rapid structural change led to the removal of many constraints on private business activity.

The resultant of these powerful developments was a state sector absorbing a high proportion of investment resources but contributing proportionately less on the supply side through employment and productivity growth.

There are several senses in which the Keynesian expansion of the past six years is unsustainable. It is unsustainable in the public finances. Huang (Chapter 4) and Wing (Chapter 3 ) in this book discuss the challenge of servicing the public debt and above all of managing the new contingent liabilities of the banking system.

The Keynesian expansion is unsustainable in its concentration of investment resources in the parts of the economy that use it least productively. If it continued much longer, it would be associated with increasingly disappointing growth performance. 
It is unsustainable in political economy terms. Reform has been a long struggle against the vested interests that have inevitably grown around the state sector, and these have been strengthened at a time when further reduction of their power is essential for continued success of the reform process.

Fortunately, the other developments have made it possible now to withdraw the Keynesian stimulus without stopping growth. The growth in scale of the private sector, with policy and institutional reform supported by high rates of direct foreign investment, has generated new sources of demand growth. The inevitable monetisation of part of the external payments surplus is boosting private consumption and investment demand. The recent stronger and more broadly based demand expansion has tightened the utilisation of productive capacity in many areas, and has ended the deflation that has troubled policymakers since the Asian financial crisis. The end of deflation itself has provided a boost to private consumption.

For the moment and for a while it seems, and will seem, that productive capacity and demand are broadly in balance. But this may turn out to be the appearance of a stopped clock showing the correct time twice each day. If there were no withdrawal of the Keynesian stimulus in the near future, the momentum in demand growth would be likely to push the economy into unsustainable over-expenditure, manifested in the re-emergence of inflationary pressures and rapid movement of the current account of the balance of payments from surplus into deficit. Developments along these lines were postponed in the first half of 2003 by the negative effects of SARS (analysed by McKibbin and Lee, Chapter 2), but will re-emerge now as the effects of the epidemic pass into history.

In these circumstances, the rate of expansion in public expenditure and investment by state-owned enterprises could be cut back without endangering growth performance. If this step were taken now, the emerging problems of public debt and contingent liabilities, of wasteful over-investment within large state enterprises, and of emerging excess domestic demand can be corrected before they damage longterm macroeconomic performance.

\section{THE UNDERVALUED YUAN}

The exuberance about Chinese growth, the external payments surplus and above all the bilateral trade surplus with the United States have led in 2003 to calls from foreign business and Governments for China to abandon the nine-year-old peg of the yuan against the US dollar. The call has mostly been for the floating of the 
currency in the expectation that this would lead to a large appreciation. Some calls have been for an appreciation of the yuan within the framework of the established peg against the US dollar.

The current official peg against the US dollar was adopted in early 1994 as part of a currency reform that embodied the integration of official and 'grey market' foreign exchange rates. Prior to these developments, the yuan had been loosely pegged to the US dollar, but uninhibitively devalued from time to time to correct recurrent external payments weakness that had there origins in rates of demand expansion and inflation that were high relative to the rest of the world, at a time of rapid trade and payments liberalisation. Since the 1994 reforms, the yuan has been firmly fixed to the US dollar, although in the year immediately preceding the Asian financial crisis there was discussion of moving to a floating rate by the end of the twentieth century.

In the lead-up to the foreign exchange market unification, the yuan had been going through one of its more pronounced periods of overvaluation, on the back of the huge boom in domestic investment triggered by Deng Xiaoping's exhortations to accelerate reform and growth on his famous last journey to the south of China. The overvaluation was reflected in large premia over the official rate on the black market and the officially-sanctioned grey market. The unification of the foreign exchange market at a rate close to the 'grey market' level represented a substantial devaluation for firms operating at the official exchange rate (principally the large state-owned corporations) but not for the foreign joint ventures and many others who had access to the officially-sanctioned 'grey market'. This partial devaluation was seen as underpinning China's competitiveness through a period of accelerated trade liberalisation, and in practice had this effect.

The unified official exchange rate, pegged against the US dollar, came under downward pressure through the Asian financial crisis, when the East Asian economies went into recession and experienced large devaluations of their own. These economies together absorbed almost half of China's exports and were China's most intense competitors in exports to global markets. China's payments came under pressure, prompting large efforts to accelerate reform to make China more attractive for direct foreign investment and to raise productivity in the export industries. There was frequent comment through 1998 that the yuan would need to be devalued. The Chinese authorities responded that such action would not be helpful to the Chinese economy and would undermine the attempts by other East Asian economies to restore stability in the aftermath of financial crisis. 
From time to time through 1998 the peg against the US dollar came under speculative attack, directly, and by proxy through speculative sale of the more exposed HK dollar. The attacks on the HK dollar could be resisted because of the Special Administrative Region's exceptional levels of fiscal and monetary reserves. Speculation directly against the yuan was never effective because of China's retention of foreign exchange controls on international capital movements. Some controls on use of foreign exchange were made more restrictive. This episode, and parallel observation of the contribution of large-scale fluctuations in capital movements to macroeconomic instability elsewhere in East Asia at this time, led the Chinese authorities to announce indefinite postponement of any movement towards a floating exchange rate and a more open capital account.

China's strategy of seeking to maintain growth through the Asian financial crisis with public sector demand expansion and a fixed exchange rate worked well for China and the international economy. Import growth remained positive in China when it was contracting elsewhere in East Asia. This helped to moderate the downward spiral of import contraction and slower economic growth that was at the centre of the contagion that continued after the initial recessionary impetus from the financial markets. Until 2001 , the only questions about the sustainability of the peg focussed on yuan weakness.

The strategy depended on the judgment that the East Asian economies would in a relatively short period-no more than a couple of years-emerge from recession, have their currencies stabilise and then strengthen against main currencies outside the region, and return to import expansion. These developments would have to occur early enough for China to ease the domestic stimulus before the macroeconomic imbalances that they would produce had themselves caused major problems for sustainable growth in China.

In the event, the judgment was validated by the trajectory of East Asian recovery from late 1998. The sustainability of the strong yuan policy was supported by Chinese deflation, which generated some depreciation of the real exchange rate even at a time of low inflation in industrial countries. The macroeconomic strategy had been proven to have been successful before the depreciation of the US dollar, and with it the yuan, against most currencies between late 2002 and mid 2003 added to emerging concerns that the Chinese currency may have entered a period of undervaluation.

Both exports and imports have increased rapidly since 1998. Chinese import expansion accounted for around one-quarter and exports for the whole of the world 
total in the two years from 2000. The faster export expansion has been associated with a significant current account surplus, amounting to US $\$ 21$ billion or 1.7 per cent of GDP in 2002.

This is the context of the growing clamour for appreciation of the yuan. The claim that rapid export growth deriving from an undervalued yuan is causing unwarranted pressure for manufacturing production and employment to decline in the rest of the world has become part of United States' electoral politics in 2003 , with dangerous implications for the political economy of protection in that country. The pressure on Chinese exchange rate policy reached a new height during the visit of United States Treasury Secretary Snow to Beijing in late August 2003. The Secretary's representations were met by a Chinese response that it would eventually free up the foreign exchange market, but not yet.

If China had had a freely floating currency, it would probably have depreciated with its East Asian neighbours in 1997 and 1998, and appreciated with the tendency towards payments surplus since 2001 . China with a freely floating and at first a depreciating currency would have found it neither necessary nor feasible to embark on the huge Keynesian fiscal expansion of these last six years. China would have contributed less to holding up East Asian and global trade through and in the immediate aftermath of the East Asian crisis, but would probably have placed less strain on the global trade and payments system in the current, less inherently dangerous circumstances.

Would it make sense for China now to liberalise capital transactions in its foreign exchange markets and float the yuan? Not unless and until China has taken reform of its financial system to the point where its financial institutions can be expected to respond with foresight and flexibility to the huge flows of capital and their reversal over short periods that is a normal feature of contemporary international financial affairs. China is not yet at that point. Priority needs to be given to financial system reform, including facilitation of the emergence of strong private banks, and to effective imposition of hard budget constraints on state-owned enterprises generally through privatisation or other means. Important aspects of financial sector reform are discussed in the contributions to this book by Huang (Chapter 5 ), Shan (Chapter 6) and Cheng (Chapter 7).

Pending the necessary progress on reform, would discrete revaluation of the yuan, without liberalisation of the foreign exchange markets, be helpful to Chinese and international macroeconomic stability? 
It is hard to see how a minor adjustment, achieved through widening the band in which the yuan exchange rate is set against the US dollar, would be at all helpful. But is there a case for a larger, discrete revaluation?

Perhaps, if the current tendency towards external payments surplus were expected to be of large dimension over a long period. However, the current account surplus does not seem to have these characteristics. It is likely to fall quickly as the acceleration in domestic demand expansion, itself deriving to a considerable extent from monetisation of part of the external payments surplus, together with recent measures to liberalise trade and payments, flow quickly into increased imports. Indeed, in the first seven months of 2003, the import growth of 43 per cent in US dollars exceeded export growth of 33 per cent over the corresponding period of 2002. The time that China has bought in its discussions with the Treasury Secretary will probably be enough for the fragility of the current account surpluses to become widely apparent.

The capital account surpluses are contributing a large component of China's accumulation of foreign exchange reserves. Since the capital inflow takes the form of direct foreign investment to an unusual degree, it seems at first sight that this element of the external payments surplus would be more durable, and therefore make a stronger case for yuan appreciation. Closer analysis raises questions as well about the durability of this element of the payments surplus. When high levels of direct foreign investment were associated with weak external payments generally and speculation about yuan devaluation during and in the aftermath of the Asian financial crisis, they were accompanied by high levels of net capital outflow in other forms. Speculators ultimately found ways around the capital controls through leads and lags in current payments and variations in the ratios of locally sourced to imported capital associated with direct foreign investment. All of these mechanisms have gone into reverse in the current period of speculation about yuan appreciation. The capital controls inhibit but do not completely block the speculative movement of capital, and the residual movements are closely correlated with the balance and direction of change of the current account. The large contemporary surpluses on the capital account are likely to diminish as the current account moves from large surplus towards deficit.

To the extent that the downward adjustment of the Chinese external payments surplus as a result of the processes described as being too slow or incomplete, there is a stronger case for China to accelerate the growth in imports through faster 
trade and payments liberalisation rather, than through currency appreciation. The pace of trade liberalisation is currently impressive, as China meets the far-reaching conditions on its entry into the WTO. But the barriers to international trade at China's borders will remain considerable after the completion of the currently agreed program. It is open to China to accelerate the implementation of the current WTO commitments, and to move beyond them. China has done something of each of these things, most recently with the announcement of liberalisation of restrictions on money taken abroad by tourists and other travellers. Going further in this direction would contribute to macroeconomic adjustment in much the same way as currency appreciation. However, it would have a more favourable impact on the efficiency with which domestic resources were used. And it would have a favourable effect on global discussions of trade liberalisation at a time when the Doha round of multilateral trade negotiations is experiencing trouble for want of trade liberalisation leadership in any major economy.

\section{CHINA'S GROWTH AND THE WORLD COMMUNITY}

As China, with a fifth of the world's people, moves towards the average productivity levels of industrialised countries, it inevitably comes to assume a large place in the fortunes of other countries and of the world economy. This is a natural and inevitable process. It should take no-one by surprise, although it does involve radical rearrangement of power relationships in the global economy and eventually the world's political system.

If China's reform and economic growth proceed broadly along the lines of the past twenty five years-and that is the most likely course, despite the bumps in the road, the detours and dead-ends that will inevitably be part of such a long and complicated story - then China will catch up with the United States in total economic size more quickly than is commonly supposed. I discussed the economics and the arithmetic of catching up with the United States in chapter one of China 2002: WTO entry and world recession (Garnaut and Song 2002). It would not be at all surprising if China were the world's largest economy by all the relevant way of measuring economic size within a few decades.

China's foreign trade and investment have been growing even more rapidly than its economic output, absolutely and in comparison with the rest of the world. This follows partly from the reform and growth strategy, which from the beginning have emphasised deep integration into the global economy. The tendency is also promoted 
by the considerable and increasing concentration of Chinese economic activity and population in coastal cities and provinces and up the Yangtze River with relatively easy access to the coast. It is reinforced by the highly skewed nature of China's resource endowments relative to other major participants in international trade, endowments which expand opportunities for profitable international exchange. China's growing and changing role in international trade are discussed by Song and Sun (Chapter 10), Tong (Chapter 9), Tang (Chapter 15), Wu (Chapter 16), and Chang and Tyers (Chapter 14). Some implications for the world and Asia Pacific trading systems are the focus of the contributions by Raby (Chapter 8 ) and Findlay (Chapter 11).

The emergence of China as an increasingly large and internationally oriented economy generates opportunities and challenges for the rest of the world. There are opportunities for incomes growth through greater specialisation by other countries in what they do best. Utilisation of this opportunity is especially valuable at a time of diminished economic dynamism in much of the world. The challenges are the other side of the same coin. The utilisation of opportunity requires the transfer of resources from activities that compete directly with emerging comparative strengths of China, into others in which China's trading partners have stronger comparative advantage as a result of the growth of China and its increased participation in international exchange. There are short-term adjustment costs, and negative domestic political reactions.

Geography matters in international trade, and the largest positive and negative effects of China's emergence as a major trading economy are close to China in the Western Pacific region. Pacific Economic Outlook 2003 discusses major effects of mainland China's growth on the economic outlook for Japan, Korea, Hong Kong, Chinese Taipei and the economies of Southeast Asia (PECC 2003). Australians are closely aware that elements of recent strength in international markets for minerals, metals, petroleum and agricultural products and services (notably education and tourism) have origins in Chinese demand.

East Asian economies are also experiencing tendencies towards 'hollowing out' of old manufacturing industry, as competitive productive capacity expands in China. Most analysts as well as political leaders in the Western Pacific have taken the view that the net effects are positive, but there are still costs and negative perceptions to be managed. 
More recently, there has been wider international concern about the shift of global manufacturing capacity to China. Some political discussion in the United States in 2003 has identified growing imports from China as a significant factor in the decline in manufacturing employment, and the under-valuation of the yuan as a contributing cause. While the arithmetic of increased imports from China and decline of manufacturing employment in large industrial countries does not suggest strong causation, there is no doubt that the issue has political traction.

China's growth and integration into the international economy can go badly wrong if reactions to the costs of adjustment to rapid structural change become influential in political processes at home or abroad. The nature of domestic and international institutions through which political reactions to structural change are mediated can therefore have an important influence on the sustainability of growth.

China's institutions for managing resistance to structural change are weak. That partly reflects the traditions of a highly centralised political system, in which leaders have not had to pay attention to day to day community reactions to policy. Improvements in education and in communications amongst Chinese, greater freedoms of movement and association and what could be described as the democratisation of daily life (as distinct from the democratisation of the political superstructure) are increasing the openness of policymaking processes to community pressures. The chances of political resistance leading to partial retreat from open policies would be reduced if China developed domestic institutions that had credibility as sources of independent (from government and business direction) and transparent analysis of the costs and benefits of trade policy changes (see Carmichael and Garnaut (2003) for more general articulation of this point).

The WTO is the most important of the international institutions in mediating pressure for restrictive reactions to adjustment pressures arising from the rapid growth of Chinese foreign trade. Chinese (and Chinese Taipei) membership from late 2003 has reduced the risk that reactions to domestic political pressures in China or in its trading partners would ever block expansion of profitable trade relations between China and the rest of the world. The value of China's WTO membership for productive expansion of trade has been enhanced by several innovations in the Uruguay Round of multilateral trade negotiations. The most important of the Uruguay Round developments for China were the strengthened disputes settlements mechanism, 
the constraints on agricultural subsidies, and the complete phasing out of the multifibres arrangement and with it quantitative restrictions on imports of textiles and clothing by 2005 in the high-income countries of the North Atlantic.

China's membership of the WTO has delivered the benefits for China and the world that had been sought in negotiations on entry conditions. China has been disappointed at the extent of other countries' recourse to anti-dumping devices and has responded by making more use of them itself. This is a development with potential significantly to reduce benefits to China and its trading partners of internationally oriented growth in China. Constraints on protectionist uses of antidumping arrangements are an important Chinese interest in the new, Doha Round of multilateral trade negotiations, alongside the expansion of market access in many areas that is necessary to maintain international interest in and support for the multilateral system. China has been inclined so far to take a back seat in the Doha Round, in the belief that the substantial liberalisation which it has effected in recent years or to which it has already committed will be recognised as a substantial contribution that obviates the need for further initiatives ahead of a comprehensive settlement of the issues. However, China's economic dynamism in a world that is struggling for sustained growth, and its external payments surpluses, place it in a good position to take a lead in global trade liberalisation in the Doha Round, at a time when the WTO is lacking clear leadership on trade liberalisation from other countries.

Findlay (Chapter 11) discusses one surprising and troubling feature of contemporary Chinese trade policy: the recent interest in discriminatory trading arrangements, especially with East Asian trading partners. It is surprising because the dimensions of Chinese trade expansion suggest the advantages of specialisation in line with global comparative advantage Trade on a non-discriminatory basis in China and its trading partners allows the adjustment stresses of Chinese trade expansion to be spread broadly through the international community. This would seem to be the logic of China's recent membership of the WTO, the benefits of which have been explained extensively within China.

Preferential trading arrangements concentrate pressures of adjustment disproportionately amongst favoured partners. To the extent that discriminatory trading arrangements were with East Asian partners, it would compound the tendency for economic geography to concentrate adjustment costs in this region. The absorption of the huge expansion in Chinese trade that follows naturally from China's open 
policies is accommodated most easily within a global trading system. The breakdown of the multilateral trading system into small-group free trade areas, with East Asian and some other Asian partners inside, and the United States, the European Union and some others outside, would greatly complicate international accommodation to internationally oriented growth in China. It would increase the chances that protectionist response to the costs of adjustment in China or elsewhere would bring slow the productive process or even bring it prematurely to an end.

The implications of Chinese growth for the international political system are even more complex. Two years ago, it seemed that feelings of strategic rivalry with a rapidly growing China in the young administration of George W. Bush in the United States may lead to such serious conflict that productive economic relations would be at risk. These risks subsided with the United States focus on the war against terrorism, in which China was seen as a helpful ally, and the security crisis on the Korean peninsular, in which China was seen as an essential contributor to any satisfactory solution. China has worked to build a less problematic relationship with the United States more generally in this new context, and the United States has reciprocated the efforts. Austin discusses these important developments in Chapter 24.

\section{RESPONSES TO GROWING INEQUALITY}

Of the many innovations in doctrine and policy that were necessary conditions for the success of the reforms from 1978, none were more important or difficult than the acceptance of wider dispersion in the distribution of incomes and wealth amongst the people of mainland China.

Three aspects of the Chinese reforms made their effects on inequality of wealth and incomes benign in the early years.

First, China's reforms had their first large impact on farming, with the rapid replacement of almost all the People's Communes by the household responsibility system in agriculture between 1978 and 1984. Alongside the institutional transformation, the removal of the bias against agriculture in the old central planning system was associated with an increase in the price of farm products relative to manufactured goods purchased by farmers. Agricultural output and real farm incomes rose rapidly all over China. This was highly favourable to equitable income distribution in the early years of reform.

Second, China is a relatively densely populated country, especially in coastal areas, with comparative advantage in labour-intensive products in the early stages 
of development. This meant that opening up to foreign trade generated exceptionally strong growth in labour-intensive industries. This caused many of the early gains from trade to be passed directly to labour and therefore distributed widely through the community through the operation of the labour market.

Third, the provinces with the highest average incomes at the beginning of the reform period were the favoured locations for heavy industry and other activities which were concentrated in large, state-owned enterprises. These included Shanghai and the provinces of Northeast China. By contrast, the early beneficiaries of reform were provinces with opportunities to take full advantage of agricultural reform, growth in township and village industries and international exports of labour-intensive products. These were led by Guangdong, Zhejiang and Jiangsu, the rapid growth of which for a few years involved catching up with some other provinces.

So until the mid eighties, reform was favourable to equitable income distribution. For a few years after that, it was, at worst, ambiguous in its effects.

That all changed in the 1990s and the early twenty first century. The further development of the market economy has greatly widened the dispersion of the distribution of personal incomes and wealth. At the top of the distribution, and inevitably in a market economy, there are concentrations of wealth. Meng (Chapter 17) shows that these are correlated with political privilege. Rural-urban income gaps have widened markedly, exacerbated by a partial retreat from the use of market mechanisms to allocate resources within agriculture, and by the favoured position of large-scale state-owned enterprises through the period of Keynesian fiscal expansion. The distribution of income amongst provinces has widened as the more successful coastal provinces have continued to grow rapidly after their average incomes have come to exceed those of the provinces that had been favoured by central planning.

Many elements of the contemporary economic reform program are widening still further the interpersonal, inter-sectoral and interprovincial income gaps. Loss of jobs associated with restructuring of state-owned enterprises has made unemployment a significant contributor to inequality amongst individuals and households. Inequality in the interpersonal distribution of income continues to widen as the private sector matures and expands its role (Mei, Chapter 20). Direct foreign investment is concentrated in coastal provinces with high average incomes (Chen, Chapter 12). The opportunities for incomes growth that are created by trade 
liberalisation are concentrated disproportionately in coastal China-even in agriculture, where WTO entry favours the labour-intensive production of the coastal provinces and forces contraction in the land-intensive production of the inland.

These developments have the potential to undermine political support for reform and productivity-raising structural change. They have generated much discussion of and some action on policy change to moderate adverse effects of reform on income distribution. Recent developments in policy with implications for the moderation of income inequality are discussed in Wang and Duncan (Chapter 13), Qun (Chapter 18), Murton (Chapter 19), Golley (Chapter 22), Houghton and Davies (Chapter 21) and Jiang and Zhao (Chapter 23).

\section{THE PATH AHEAD}

China's reform and growth have recently emerged from a sustained period of adverse external conditions. Chinese economic strategy was successful in maintaining domestic growth momentum during this period, and in the process was helpful to economic activity abroad at a difficult time for East Asia and much of the world economy.

The current environment appears to be more benign. In some senses it is. But it is dangerous to forget the dimensions of the reform task that lies ahead. Focus in the policy discussion is containing larger components on measures to moderate the income distribution of effects of contemporary reform. It is inevitable that the debate on the income distribution issues will become intertwined with a debate on the more sensitive question of the distribution of political power. The maintenance of reform momentum and political stability will require wise leadership and steady achievement in these areas.

The outstanding agenda of reform of economic institutions, with the financial system first of all, contains immense challenge. There is unlikely to be a dramatic financial crisis, but failure to make steady process is likely to be associated with attrition of economic performance to an extent that soon shows up in the growth statistics.

The current over-excitement about China in international business will be brought to heel as realisation spreads that China's external strength is of modest dimension, as the strong domestic demand growth is instrumental in turning a current account surplus into a deficit over a short time. Observers who hold the view that China's 
economic success is a positive development for people everywhere will then be glad that Chinese economic leaders kept their feet on the ground when foreigners talked of the need for huge exchange rate appreciation in mid 2003. Maybe this time the foreign misperception can be corrected without over-reaction. Because, for all the problems and risks which lie ahead, China's emergence as a modern, internationally oriented economy will remain the big story of world economic history for some time yet.

\section{REFERENCES}

Carmichael, B. and Garnaut, R., 2003. Open Letter to the Prime Minister and Leader of the Opposition, The Australian National University, Canberra.

Garnaut, R. and Song, L., 2002. China 2002: WTO entry and world recession, Asia Pacific Press, Canberra.

Pacific Economic Cooperation Council, 2003. Pacific Economic Outlook 2003-04, Asia Pacific Press, Canberra.

State Statistical Bureau, various years. Zhongguo Tongji Nianjian [China Statistical Yearbook], Zhongguo Tongji Chubanshe, Beijing. 